\title{
PENGARUH PRODUK TERHADAP KEPUTUSAN PEMBELIAN INDOMIE GORENG DENGAN VARIABEL PROMOSI SEBAGAI MODERASI DI PT. INDOMARCO ADI PRIMA CABANG LUBUKLINGGAU
}

\author{
Supriyanto $^{1}$, Lara Alfionita ${ }^{2}$ \\ ${ }^{1,2}$ Program Studi Manajemen, Universitas Bina Insan Lubuklinggau \\ E-mail : ${ }^{1}$ supriyanto@univbinainsan.ac.id, ${ }^{2}$ laraalfionita@gmail.com
}

\begin{abstract}
ABSTRACK
This research was conducted at PT. Indomarco Adi Prima Lubuklinggau Branch. The purpose of this study is to determine the effect of the product on purchasing decisions with promotion variables as moderation at PT. Indomarco Adi Prima Lubuklinggau Branch partially and simultaneously. The data collection technique used was a questionnaire. Respondents were consumers at PT. Indomarco Adi Prima Lubuklinggau Branch. The results of the research The effect of the product on the purchasing decision of Indomie Goreng, obtained $t_{\text {count }} v a l u e$ of 3,797 and $t_{\text {table }}$ is $0.1638\left(t_{\text {table }}\right.$ value $\left.n=100\right)$ so it can be seen that if the criteria match $t_{\text {count }}>$ tta $t_{\text {table }}$ ble then $\mathrm{Ho}$ is rejected and $\mathrm{Ha}$ is accepted, which means that there is an influence. There is a significant difference between the product and the purchase decision of Fried Indomie, promotional moderation can strengthen the purchasing decision of Fried Indomie, the tcount is 5,261 and the $t_{\text {table }}$ is 0.1638 ( $t_{\text {table }}$ value $n=100$ ), then it can be seen that if the criteria are in accordance with $t_{\text {count }}>t_{\text {table }}$ then $\mathrm{Ho}$ rejected and $\mathrm{Ha}$ accepted, which means that there is a significant influence between promotion and purchasing decisions Indomie Goreng, product influence, and promotion can strengthen Indomie Goreng purchasing decisions, That the effect of products on purchasing decisions is $12.8 \%$. As well as the test results after the moderation variable, namely promotion can strengthen or increase purchasing decisions to $36.2 \%$.
\end{abstract}

Keywords : Purchase, Promotion, Product Decisions

\begin{abstract}
ABSTRAK
Penelitian ini dilakukan di PT. Indomarco Adi Prima Cabang Lubuklinggau. Tujuan penelitian ini mengetahui pengaruh produk terhadap keputusan pembelian dengan variabel promosi sebagai moderasi di PT. Indomarco Adi Prima Cabang Lubuklinggau secara parsial dan simultan. Teknik pengumpulan data yang digunakan adalah kuisioner yang menjadi responden penelitian adalah konsumen di PT. Indomarco Adi Prima Cabang Lubuklinggau. Hasil penelitian Pengaruh produk terhadap keputusan pembelian Indomie Goreng, didapatkan Nilai $t_{\text {hitung }}$ sebesar 3.797 dan $\mathrm{t}_{\text {tabeladalah sebesar }} 0.1638$ (nilai $\mathrm{t}_{\text {tabel }} \mathrm{n}=100$ ) maka dengan demikian dapat diketahui bahwa jika kriteria sesuai dengan $t_{\text {hitung }}>t_{\text {tabel }}$ maka Ho ditolak dan Ha diterima, yang artinya ada pengaruh signifikan antara Produk dengan keputusan pembelian Indomie Goreng, Moderasi promosi dapat memperkuat keputusan pembelian Indomie Goreng, didapatkan nilai thitung sebesar 5.261 dan $t_{\text {tabel }}$ adalah sebesar 0.1638 (nilai $\mathrm{t}_{\text {tabel }} \mathrm{n}=100$ ) maka dengan demikian dapat diketahui bahwa jika kriteria sesuai dengan $t_{\text {hitung }}>t_{\text {tabel }}$ maka Ho ditolak dan Ha diterima, yang artinya ada pengaruh signifikan antara promosi dengan keputusan pembelian Indomie Goreng, Pengaruh produk, dan Promosi dapat Memperkuat keputusan pembelian Indomie Goreng, Bahwa pengaruh produk terhadap keputusan pembelian adalah sebesar $12.8 \%$. Serta hasil pengujian setelah adanya variabel moderasi yaitu promosi dapat memperkuat atau meningkatkan keputusan pembelian menjadi $36.2 \%$.
\end{abstract}

Kata kunci : Keputusan Pembelian, Promosi, Produk 


\section{PENDAHULUAN}

Perkembangan bisnis di era saat ini berdampak pada perubahan aktivitas manusia terutama pada segi perilaku pesaingan didalam menjalankan bisnis. Setiap perusahaan berlomba untuk menjadi yang paling baik dalam ruang lingkup bisnis yang dijalankan. Setiap pemasaran yang dijalankan setiap perusahaan dapat memberikan serta memenuhi setiap kebutuhan manusia.

Pemasaran merupakan proses sosial serta manajerial untuk setiap orang atau kelompok untuk mendapatkan apa yang diinginkan dengan menciptakan dan saling bertukar produk atau jasa ataupun nilai antara seseorang dengan yang lainnya [1]. Kegiatan pemasaran perlu diberi perhatian lebih sehingga lebih mempengaruhi keputusan pemebelian dari setiap produk yang dipasarkan.

Menurut Kotler dan Keller dalam penelitian Lucius Hermawan, produk yaitu keseluruhan untuk ditawar kepada setiap pasar yang bertujuan memberikan kepuasan sesuatu yang menjadi kebutuhan terdiri dari barang fisik, jasa, pengalaman, acara, orang tempat, organisasi, properti, informasi, organisasi, ide serta informasi [2]. Kategori yang tergolong terbaik akan bertahan dalam sebuah industri perusahaan. Termasuk industri perusahaan makanan yang berubah karena terdapatnya aktifitas dari setiap individu atau kelompok berdampak konsumsi makanan yang juga berubah.

Berbagai varian produk yang ada memberikan opsi pilihan yang banyak untuk konsumen dapat menjatuhkan pilihan yang mereka inginkan. Hal tersebut berdampak pada kondisi konsumen untuk memilah dengan baik dari berbagai pilihan ada saat ini. Setiap perusahaan harapnya dapat memproduksi beragam jenis pilihan dibutuhkan konsumen sehingga dihasilkan produk dapat bersaing dan menjadi alternatif pilihan utama konsumen.

Salah satu proses kegiatan yang dapat memberikan pengaruh untuk membeli yang diinginkan konsumen seperti memberikan promosi dari berbagai pilihan barang dari perusahaan. Menurut Kotler dan Keller dalam penelitian Yulianita Wiwid Susanto menjelaskan suatu kebijakan harga yang terdapat pada suatu produk dapat memberikan pengaruh untuk penentuan dalam pemasaran dimana harga menjadi unsur terpenting yang memberikan pendapatan untuk setiap perusahaan [3]. Dari penjelasan tersebut mendefiniskan harga yang juga didapat dalam keputusan promosi untuk perusahaan.

Kegiatan promosi yang dapat dilakukan oleh perusahaan berguna sebagai proses pengenalan barang kepada pelanggan. Terdapat sarana promosi yang dapat dilakukan oleh perusahaan seperti (1) periklanan, (2) promosi penjualan, (3) publisitas dan (4) penjualan pribadi [4]. Promosi akan dapat menciptakan sikap yang baik terhadap barang yang akan dijual oleh perusahaan, sehingga dengan dengan positif mempengaruhi perasaan dan emosi pelanggan untuk menjadi keyakinan atas keputusan pembelian.

Keputusan pembelian adalah perilaku sengaja dilandaskan pada keinginan yang dihasilkan ketika konsumen secara sadar memilih salah satu di antara alternatif yang ada [5]. Hal tersebut menjadikan keputusan pembelian sebagai tolak ukur untuk penentuan keberhasilan target pemasaran. Untuk itu perusahaan harus lebih memperhatikan strategi yang dapat meningkatkan keputusan pembelian terhadap produk yang dijual perusahaan.

Saat ini perusahaan yang menjadi distributor resmi untuk melakukan pemasaran dan promosi produk indomie yaitu PT. Indomarco Adi Prima. Visi dan misi dari perusahaan ini yaitu (1) visi : Menjadi distributor terbaik dan (2) Misi : Menyajikan produk-produk fresh atau segar dan berkualitas untuk seluruh konsumen. Perusaahaan ini menyediakan berbagai 
varian produk indomie salah satunya indomie goring, yang mendapatkan banyak persaingan dengan produk mie instan lainnya yang memberikan varian berbagai jenis rasa pilihan.

Berdasarkan observasi atau pengamatan langsung yang dilakukan peneliti di PT. Indomarco Adi Prima Cabang Lubuklinggau. Terdapat permasalahan pada produk seperti produk yang ditawarkan tidak sesuai dengan gambar kemasan produk, hidangan produk tidak mengugah selera, rasa produk kurang baik dengan selera konsumen serta tekstur indomie goreng kurang baik dengan selera konsumen.

Begitu juga dengan promosi yang telah dilakukan oleh dilakukan oleh PT. Indomarco Adi Prima Cabang Lubuklinggau, terdapat permasalahan bahwa perusahaan melakukan penginformasikan indomie goreng kurang baik, promosi yang telah dilakukan tidak mempengaruhi konsumen untuk membeli serta strategi promosi terlalu membujuk konsumen. Menurut Kotler dan Armstrong dalam penelitian Marceline Livia Hedynata dan Wirawan menjelasakan promosi (Promotion) merupakan suatu unsur yang digunakan untuk memberitahukan dan membujuk pasar tentang produk atau jasa yang baru pada perusahaan melalui iklan, penjualan pribadi, promosi penjualan, maupun publikasi [6]. Persaingan dengan berbagai produk mie instan goreng lainnya mengharuskan perusahaan untuk dapat berinovasi melakukan kegiatan promosi yang bertujuan untuk tetap bertahan dan bersaing dengan produk lainnya.

Keputusan pembelian juga menjadi permasalahan yang ada pada perusahaan PT. Indomarco Adi Prima Cabang Lubuklinggau, dimana saat ini produk indomie goreng yang kurang menarik tampilan, rasa yang tidak sesuai dan tidak dilakukan strategi promosi yang baik mengakibatkan keputusan pembelian di PT. Indomarco Adi Prima Cabang Lubuklinggau menurun. Dengan hal tersebut menjadikan PT. Indomarco Adi
Prima Cabang Lubuklinggau tidak memiliki tolak ukur untuk dapat merubah strategi pemasaran sehingga minat dari keputusan pemebelian dapat ditingkatkan.

Sehubungan dengan hal diatas, maka penulis akan melakukan penelitian untuk mengetahui apakah terdapat pengaruh sebuah produk sebagai keputusan pembelian produk indomie goreng dengan promosi sebagai variabel moderasi pada PT. Indomarco Adi Prima Cabang Lubuklinggau.

\section{TINJAUAN PUSTAKA}

\subsection{Keputusan Pembelian}

Definisi lainnya menjelaskan, menurut Kotler pada penelitian Yusup dan Ronal Aprianto menjelaskan keputusan pembelian merupakan tindakan dari konsumen untuk mau membeli atau tidak terhadap produk. Dari berbagai faktor yang mempengaruhi konsumen dalam melakukan pembelian suatu produk atau jasa, biasanya konsumen selalu mempertimbangkan kualitas, harga dan produk sudah yang sudah dikenal oleh masyarakat [7].

Dari penjelasan keputusan pembelian diatas maka dapat disimpulkan keputusan pembelian yaitu perilaku sengaja dilandaskan pada keinginan yang dihasilkan ketika konsumen secara sadar untuk mau membeli atau tidak terhadap produk.

\subsection{Produk}

Definisi produk produk menurut Kotler dan Keller dalam penelitian Lucius Hermawan menjelasakan produk merupakan keseluruhan yang dapat diproses untuk ditawar kepada setiap pasar yang bertujuan memberikan kepuasan sesuatu yang menjadi kebutuhan yang terdiri dari barang fisik, jasa, pengalaman, acara, orang tempat, organisasi, property, informasi, organisasi, ide serta informasi [2].

Sedangkan menurut Perreault menjelaskan, produk merupakan hasil dari produksi yang akan dilempar kepada konsumen untuk didistribusikan dan 
dimanfaatkan konsumen untuk memenuhi kebutuhannya [4].

\subsection{Promosi}

Promosi merupakan kegiatan yang dilakukan perusahaan dalam upaya mengkomunikasikan suatu produk kepada konsumen sehingga mempengaruhi minat beli konsumen terhadap produk perusahaan. Adapun kegiatan-kegiatan yang termasuk dalam promosi adalah advertising, personal selling, sales promotion, publicity, dan public relation [4].

Definisi lainnya menurut Kotler dan Armstrong dalam penelitian Marceline Livia Hedynata menjelaskan promosi (promotion) merupakan suatu unsur yang digunakan untuk memberitahukan dan membujuk pasar tentang produk atau jasa yang baru pada perusahaan melalui iklan, penjualan pribadi, promosi penjualan, maupun publikasi [6].

\subsection{Penelitian Terdahulu}

1. Desy Purwanti Atmaja dan Martinus Febrian Adiwinata, 2016 [11]. Pengaruh Produk, Harga, Lokasi Dan Kualitas Layanan Terhadap Keputusan Pembelian Di Kopitiam Oey Surabaya. Faktorfaktor yang mempengaruhi keputusan konsumen dalam melakukan pembelian (produk, harga, lokasi, dan kualitas layanan) mempunyai pengaruh positif terhadap keputusan konsumen dalam melakukan pembelian di Kopitiam Oey. Hal ini didasarkan dari hasil uji $\mathrm{F}$ dimana $\mathrm{F}$ hitung > F tabel ( $19.88>$ 2.450).

2. Riyono dan Gigih Erlik Budiharja, 2016 [4]. Pengaruh Kualitas Produk, Harga, Promosi Dan Brand Image Terhadap Keputusan Pembelian Produk Aqua. hasil analisis diketahui bahwa kualitas produk (X1), Harga (X2), Promosi (X3) dan Brand image (X4) mempunyai pengaruh positif dan signifikan terhadap keputusan membeli konsumen air minum AQUA.
3. Yulianita Wiwid Susanto, 2017 [3]. Pengaruh Inovasi Produk, Kualitas Produk Dan Harga Terhadap Keputusan Pembelian Di Toko Roti Dan Kue Ferissa Bantul. Hasil penelitian menyimpulkan bahwa pengujian hipotesis menggunakan uji $t$ menunjukkan bahwa ketiga variabel independen yang diteliti terbukti secara signifikan berpengaruh secara parsial terhadap variabel dependen keputusan pembelian. Secara simultan variabel inovasi produk, kualitas produk dan harga memiliki pengaruh yang signifikan terhadap keputusan pembelian. Hal ini dibuktikan dengan nilai $\mathrm{F}$ yaitu sebesar 63.712 dengan tingkat signifikansi $0,000<0,05$.

\subsection{Hipotesis}

1. Terdapat pengaruh signifikan produk terhadap keputusan pembelian indomie goreng di PT. Indomarco Adi Prima Cabang Lubuklinggau.

2. Promosi menguatkan pengaruh produk terhadap keputusan pembelian indomie goreng di PT. Indomarco Adi Prima Cabang Lubuklinggau.

\subsection{Kerangka Penelitian}

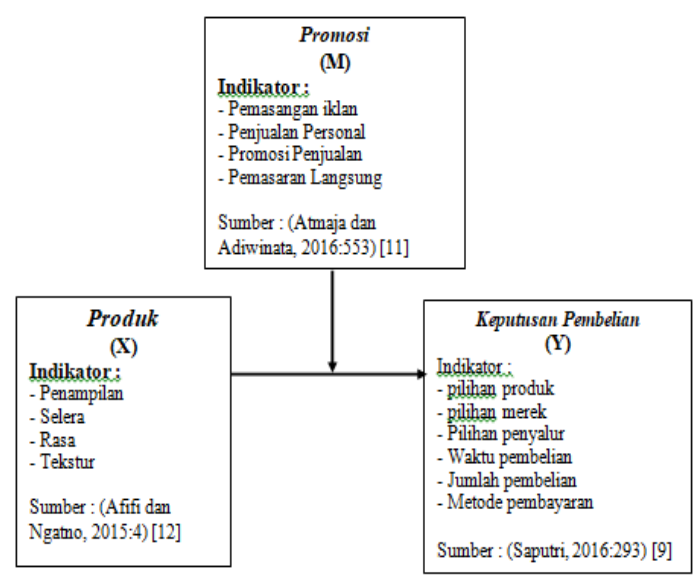

Gambar 1

Kerangka Penelitian 


\section{METODOLOGI PENELITIAN}

\subsection{Populasi dan Sampel}

\section{Populasi}

Populasi adalah wilayah generalisasi yang terdiri atas obyek/ subyek yang memiliki kualitas serta karakteristik tertentu yang diterapkan oleh peneliti untuk dipelajari dan kemudian ditarik kesimpulan [16]. Populasi pada penelitian ini merupakan keseluruhan sebagian pelanggan yang dari PT. Indomarco Adi Prima Cabang Lubuklinggau yang berjumlah 16 toko.

\section{Sampel Penelitian}

Dalam penelitian ini menggunakan rumus slovin untuk digunakan dalam pengambilan jumlah anggota sample. Rumus Slovin untuk menentukan sample penelitian adalah sebagai berikut :

$\mathrm{n}=\frac{N}{1+N(e)^{2}}$

Keterangan :

$\mathrm{n}=$ Ukuran sample/ Jumlah responden

$\mathrm{N} \quad=$ Ukuran Populasi

e $\quad=$ Presentase kelonggaran ketelitian kesalahan pengambilan sample ulang masih bias ditolerir yaitu e $=0,1$

Jadi :

$\mathrm{N}=9184$

$n=\frac{N}{1+\mathrm{N}(e)^{2}}$

$n=\frac{9184}{1+9184(0.1)^{2}}$

$n=\frac{9184}{1+9184 \cdot 0,01}$

$n=\frac{9184}{1+91,84}$

$n=\frac{9184}{92,84}$

$n=98,92$

Dari hasil diatas, maka diperoleh sample 98,82 yang dibulatkan menjadi 100 responden.

\subsection{Sumber Data}

Sumber data yang akan digunakan pada penelitian ini berasal dari sumber data primer dan sumber data sekunder. Pada penelitian ini penulis meyebarkan angkat/kuisioner kepada responden tentang Pengaruh Produk Terhadap Keputusan Pembelian Indomie Goreng Dengan Variabel Promosi Sebagai Moderasi.

\subsection{Teknik Pengumpulan Data}

Pengumpulan data dapat dilakukan dengan berbagai berbagai sumber dan berbagai cara. Dilihat dari segi cara atau pengumpulan data, maka teknik pengumpulan data pada penelitian ini akan dilakukan dengan kuisioner/ angket dan dokumentasi.

\subsection{Instrumen Penelitian}

Instrumen penelitian yang dipergunakan dalam penelitian ini berupa angket atau kuisioner yang dibuat sendiri oleh peneliti. Menurut Sugiyono menyatakan instrumen penelitian adalah suatu alat pengumpul data yang digunakan untuk mengukur fenomena alam maupun sosial yang diamati [16]. Dengan demikian, penggunaan instrumen penelitian yaitu untuk mencari informasi yang lengkap mengenai suatu masalah, fenomena alam maupun sosial. Instrumen atau alat untuk mengumpulkan data dalam penelitian ini ialah kuesioner yang dikembangkan dari variabel, indikator variabel dan definisi operasional indikator.

\subsection{Teknik Analisis Data}

Pada penelitian ini penulis akan menggunakan data kuantitatif karena metodenya menggunakan asosiatif dan jenis statistiknya menggunakan angka. Metode yang diterapkan dalam penelitian ini adalah metode asosiatif, dimana metode asosiatif akan mendefinisikan suatu pernyataan yang menunjukkan dugaan tentang pengaruh ataupun hubungan sebab akibat. Pada penelitian ini pengulis menggunakan software SPPS untuk membantu penulis 
dalam memproses pengolahan data kuisioner.

\section{HASIL DAN PEMBAHASAN}

\subsection{Hasil Penelitian}

\section{Pengujian Instrumen Penelitian a. Pengujian Validitas}

Instrumen yang valid berarti alat ukur yang digunakan untuk mendapatkan data (mengukur) itu valid. Karena $\alpha=0,05$ adan $\mathrm{N}=30$ maka dapat diketahui $\mathrm{r}_{\text {tabel }}$ Untuk pengujian ini adalah 0.361. Jadi jika korelasi antara butir dengan skor total kurang dari 0.361 maka butir dalam instrument tersebut dinyatakan tidak valid. Adapun rumus untuk menguji validitas yaitu menggunakan korelasi person (product moment) sebagai berikut, Uji validitas dilakukan pada PT. Wings Lubuklinggau untuk produk mie sedap goreng sebanyak 30 sampel.

Dari hasil pengujian menunjukan hasil uji validitas variabel produk (X) dari 12 (dua belas) pernyataan dengan sampel sebanyak 30 (tiga puluh) responden dengan standar signifikan 0,05 (5\%). Dari sig 0,05 dengan 30 responden maka $r_{\text {tabel }}$ sebesar 0,361 jika $r_{\text {hitung }}>r_{\text {tabel }}$ maka data dinyatakan valid. Dari pengujian tersebut semua item indikator berada diatas nilai terkecil 0.397 terhadap $r_{\text {tabel }}$ sebesar 0.361 . Hal ini berarti bahwa semua item pernyataan yang ada dalam kuisioner tersebut dapat dijadikan sebagai alat ukur yang valid dalam analisis selanjutnya.

Dari hasil pengujian menunjukan hasil uji validitas variabel keputusan pembelian (Y) dari 12 (dua belas) pernyataan dengan sampel sebanyak 30 (tiga puluh) responden dengan standar signifikan 0,05 (5\%). Dari sig 0,05 dengan 30 responden maka $\mathrm{r}_{\text {tabel }}$ sebesar 0,361 jika $r_{\text {hitung }}>r_{\text {tabel }}$ maka data dinyatakan valid. Dari pengujian tersebut semua item indikator berada diatas nilai terkecil 0.375 terhadap $\mathrm{r}_{\text {tabel }}$ sebesar 0.361. Hal ini berarti bahwa semua item pernyataan yang ada dalam kuisioner tersebut dapat dijadikan sabagai alat ukur yang valid dalam analisis selanjutnya.

Dari hasil pengujian diatas menunjukan hasil uji validitas Variabel Promosi (M) dari 12 (dua belas) pernyataan dengan sampel sebanyak 30 (tiga puluh) responden dengan standar signifikan 0,05 (5\%). Dari sig 0,05 dengan 30 responden maka $r_{\text {tabel }}$ sebesar 0,361 jika $r_{\text {hitung }}>r_{\text {tabel }}$ maka data dinyatakan valid. Dari pengujian tersebut semua item indikator berada diatas nilai terkecil 0.434 terhadap $r_{\text {tabel }}$ sebesar 0.361 . Hal ini berarti bahwa semua item pernyataan yang ada dalam kuisioner tersebut dapat dijadikan sabagai alat ukur yang valid dalam analisis selanjutnya.

\section{b. Pengujian Reliabilitas}

Pengujian dilakukan pada PT. Wings Lubuklinggau untuk produk mie sedap goreng sebanyak 30 sampel. Adapun hasil penelitian yaitu sebagai berikut:

\section{1) Variabel Produk (X)}

Tabel 1

Pengujian Reliabilitas Variabel

Produk

\begin{tabular}{|l|l|}
\hline \multicolumn{2}{|c|}{ Reliability Statistics } \\
\hline Cronbach's Alpha & $\mathbf{r}_{\text {tabel }}$ \\
\hline 0.862 & 0.361 \\
\hline
\end{tabular}

Sumber: Hasil Pengolahan Data Tahun 2020, SPSS Versi 21

Dari tabel hasil uji reliabilitas variabel produk $(\mathrm{X})$ diatas, nilai korelasi Cronbach Alpha $=0.862$. Korelasi berada pada tingkat Sangat Reliabel. Berdasarkan kriteria maka dapat diketahui bahwa nilai Cronbach Alpha $0.862>0,361$ maka dengan demikian dapat disimpulkan bahwa kuisioner yang akan diuji dapat dinyatakan reliabel. 
2) Variabel Keputusan Konsumen (Y)

Tabel 2

Pengujian Reliabilitas Variabel Keputusan Pembelian

\begin{tabular}{|l|l|}
\hline \multicolumn{2}{|c|}{ Reliability Statistics } \\
\hline Cronbach's Alpha & $\mathbf{r}_{\text {tabel }}$ \\
\hline 0.913 & 0.361 \\
\hline
\end{tabular}

Sumber: Hasil Pengolahan Data Tahun 2020, SPSS Versi 21

Dari pengujian diatas disimpulkan bahwa nilai korelasi Cronbach Alpha $=0.836$. Korelasi berada pada tingkat Sangat Reliabel. Berdasarkan kriteria maka dapat diketahui bahwa nilai Cronbach Alpha0.913>0,361 maka dengan demikian dapat disimpulkan bahwa kuisioner yang akan diuji dapat dinyatakan reliabel.

\section{3) Variabel Promosi (M)}

Tabel 3

\section{Pengujian Reliabilitas Variabel Promosi}

\begin{tabular}{|l|l|}
\hline \multicolumn{2}{|c|}{ Reliability Statistics } \\
\hline Cronbach's Alpha & $\mathbf{r}_{\text {tabel }}$ \\
\hline 0.919 & 0.361 \\
\hline
\end{tabular}

Sumber: Hasil Pengolahan Data Tahun 2020, SPSS Versi 21

Dari tabel hasil uji reliabilitas Variabel Promosi (M) diatas, nilai korelasi Cronbach Alpha $=0.919$. Korelasi berada pada tingkat Sangat Reliabel. Berdasarkan kriteria maka dapat diketahui bahwa nilai Cronbach Alpha0.919 > 0,361 maka dengan demikian dapat disimpulkan bahwa kuisioner yang akan diuji dapat dinyatakan reliabel.

\section{Uji Asumsi Klasik}

\section{a. Normalitas Data}

Hasil pengujian asumsi klasik pada normalitas data untuk penelitian ini yaitu sebagai berikut:

\section{Tabel 4}

Uji normalitas

One-Sample Kolmogorov-Smirnov Test

\begin{tabular}{|c|c|c|c|c|}
\hline & & PRODUK & PROMOSI & $\begin{array}{l}\text { KEPUTUSAN } \\
\text { PEMBELIAN }\end{array}$ \\
\hline \multicolumn{2}{|l|}{$\mathrm{N}$} & 100 & 100 & 100 \\
\hline \multirow{2}{*}{$\begin{array}{l}\text { Normal } \\
\text { Parameters } a \\
\text { b }\end{array}$} & Mean & 45.52 & 40.83 & 62.77 \\
\hline & $\begin{array}{l}\text { Std. } \\
\text { Deviation }\end{array}$ & 4.689 & 3.531 & 6.279 \\
\hline \multirow{2}{*}{$\begin{array}{l}\text { Most } \\
\text { Extreme } \\
\text { Differences }\end{array}$} & Absolute & .121 & .092 & .089 \\
\hline & $\begin{array}{l}\text { Positive } \\
\text { Negative }\end{array}$ & $\begin{array}{r}.071 \\
-.121\end{array}$ & $\begin{array}{r}.070 \\
-.092\end{array}$ & $\begin{array}{r}.070 \\
-.089\end{array}$ \\
\hline \multicolumn{2}{|c|}{ Kolmogorov-Smirnov Z } & 1.208 & .921 & .888 \\
\hline \multicolumn{2}{|c|}{ Asymp. Sig. (2-tailed) } & .108 & .364 & .410 \\
\hline
\end{tabular}

Sumber: Hasil Pengolahan Data Tahun 2020,

SPSS Versi 21

Untuk menganalisanya, dapat dilihat garis “ Asymp, Sig. (2-tailed)" pada tabel diatas. Untuk nilai signifikan tiap variabel lebih dari > 0,05 maka uji normalitas bisa terpenuhi. Berdasarkan hasil uji normalitas menunjukan bahwa nilai signifikan variabel produk sebesar $0.108>0,05$, Variabel Promosi sebesar $0.364>0,05$, variabel keputusan pembelian sebesar $0,410>0,05$, dapat diambil kesimpulan bahwa nilai signifikan $>0,05$ sehingga data dapat disimpulkan normal.

\section{a. Uji Linearitas Data}

Uji linearitas digunakan sebagai prasyarat dalam analisis korelasi atau regresi linear.

Tabel 5

Uji Linearitas

\begin{tabular}{|c|c|c|c|c|c|c|c|}
\hline & & & $\begin{array}{l}\text { Sum of } \\
\text { Squares }\end{array}$ & $\mathrm{df}$ & $\begin{array}{l}\text { Mean } \\
\text { Square }\end{array}$ & $F$ & Sig. \\
\hline \multirow{5}{*}{$\begin{array}{l}\text { Keputusan } \\
\text { Pembelian } \\
{ }^{*} \text { Promosi }\end{array}$} & \multirow{3}{*}{$\begin{array}{l}\text { Between } \\
\text { Groups }\end{array}$} & (Combined) & 1123.824 & $\begin{array}{l}1 \\
6\end{array}$ & 70.239 & 2.097 & .016 \\
\hline & & Linearity & 859.798 & 1 & 859.798 & 5.671 & .000 \\
\hline & & $\begin{array}{l}\text { Deviation } \\
\text { from } \\
\text { Linearity }\end{array}$ & 264.026 & $\begin{array}{l}1 \\
5\end{array}$ & 17.602 & $\begin{array}{r}.52 \\
6\end{array}$ & .919 \\
\hline & \multicolumn{2}{|c|}{ Within Groups } & 2779.886 & $\begin{array}{l}8 \\
3\end{array}$ & 33.493 & & \\
\hline & \multicolumn{2}{|l|}{ Total } & 3903.710 & $\begin{array}{l}9 \\
9\end{array}$ & & & \\
\hline
\end{tabular}

Sumber: Hasil Pengolahan Data Tahun 2020,

SPSS Versi 21 


\begin{abstract}
Berdasarkan nilai sifnifikasi (sig) diperoleh bahwa nilai deviation from linearity Sig yaitu 0.919 lebih besar dari 0.05 yang disimpulkan bahwa secara terdapat hubungan signifikan antara setiap variabel.
\end{abstract}

\section{Pengujian Hipotesis}

a. Pengaruh produk terhadap keputusan pembelian Indomie Goreng

\section{1) Regresi Linear Sederhana}

Pengujian dilakukan untuk mengetahui pengaruh produk terhadap keputusan pembelian indomie goreng, adapun hasil penelitian yaitu sebagai berikut:

\section{Tabel 6}

\section{Regresi Linier}

Coefficients ${ }^{a}$

\begin{tabular}{|c|c|c|c|c|c|}
\hline \multirow[t]{2}{*}{ Model } & \multicolumn{2}{|c|}{$\begin{array}{c}\text { Unstandardized } \\
\text { Coefficients }\end{array}$} & $\begin{array}{l}\text { Standardized } \\
\text { Coefficients }\end{array}$ & \multirow[t]{2}{*}{$t$} & \multirow[t]{2}{*}{ Sig. } \\
\hline & B & $\begin{array}{l}\text { Std. } \\
\text { Error }\end{array}$ & Beta & & \\
\hline \multirow{2}{*}{$\begin{array}{cc}\text { (Constant) } \\
\text { PRODUK }\end{array}$} & 40.941 & 5.779 & & 7.084 & .000 \\
\hline & .480 & .126 & .358 & 3.797 & .000 \\
\hline
\end{tabular}

Sumber: Hasil Pengolahan Data Tahun 2020, SPSS Versi 21

Persamaan regresi yang digunakan adalah $\mathrm{Y}=\mathrm{a}+\mathrm{bX}$, maka dapat dihasilkan persamaan dari output adalah $\mathrm{Y}=40.941$ $+0.480 \mathrm{X}$, maka hasil output SPSS maka diketahui coefficients produk sebesar 0.480 merupakan koefisien regresi, yang berarti jika instansi meningkatkan 1 satuan maka akan meningkatkan keputusan pembelian sebesar 0.480 .

\section{2) Uji Koefisien Korelasi}

Pengujian dilakukan untuk mengetahui mengetahui pengaruh produk terhadap keputusan pembelian indomie goreng, adapun hasil penelitian yaitu sebagai berikut:

\section{Tabel 7}

\section{Uji Koefisien Korelasi}

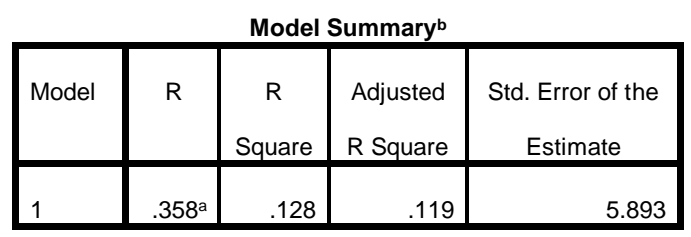

a. Predictors: (Constant), PRODUK

b. Dependent Variable: KEPUTUSAN_PEMBELIAN Sumber: Hasil Pengolahan Data Tahun 2020,

SPSS Versi 21

Hasil pengolahan data menunjukan bahwa nilai $\mathrm{R}$ atau Multiple $\mathrm{R}$ menunjukan korelasi antara variabel bebas dengan variabel terikat sebesar 0.358 Dalam hal ini karena regresi linear sederhana dapat diketahui bahwa variabel bebas maka diakatakan bahwa korelasi antara produk terhadap keputuasn pembelian adalah sebesar $35.8 \%$, dan sisanya (100-35.8= $64.2 \%)$ dipengaruhi oleh variabel lain yang tidak termasuk dalam variabel penelitian.

\section{3) Uji t}

Pengujian dilakukan untuk mengetahui pengaruh produk terhadap keputusan terhadap keputusan pembelian indomie goreng, adapun hasil penelitian yaitu sebagai berikut:

\section{Tabel 8 \\ Uji t \\ Coefficients $^{a}$}

\begin{tabular}{|c|c|c|c|c|c|}
\hline \multirow[t]{2}{*}{ Model } & \multicolumn{2}{|c|}{$\begin{array}{l}\text { Unstandardized } \\
\text { Coefficients }\end{array}$} & $\begin{array}{l}\text { Standardized } \\
\text { Coefficients }\end{array}$ & \multirow[t]{2}{*}{$t$} & \multirow[t]{2}{*}{ Sig. } \\
\hline & B & $\begin{array}{l}\text { Std. } \\
\text { Error }\end{array}$ & Beta & & \\
\hline $\begin{array}{ll} & \text { (Constant) } \\
& \text { PRODUK }\end{array}$ & $\begin{array}{r}40.941 \\
.480\end{array}$ & $\begin{array}{r}5.779 \\
.126 \\
\end{array}$ & .358 & $\begin{array}{l}7.084 \\
3.797\end{array}$ & $\begin{array}{l}.000 \\
.000\end{array}$ \\
\hline
\end{tabular}

Sumber: Hasil Pengolahan Data Tahun 2020, SPSS Versi 21

Dari data hasil pengujian maka independent yang dimasukan kedalam model regresi variabel maka dapat diketahui bahwa untuk mengetahui apakah produk memiliki pengaruh terhadap keputusan pembelian, 
didapatkan nilai $\mathrm{t}_{\text {hitung }}$ sebesar 3.797 dan $\mathrm{t}_{\text {tabel }}$ adalah sebesar 0.1638 (nilai $t_{\text {tabel }} n=100$ ) maka dengan demikian dapat diketahui bahwa jika kriteria sesuai dengan $t_{\text {hitung }}>t_{\text {tabel }}$ maka Ho ditolak dan $\mathrm{Ha}$ diterima, yang artinya ada pengaruh signifikan antara Produk dengan keputusan pembelian Indomie Goreng.

\section{b. Pengaruh Promosi Untuk Memperkuat Keputusan Pembelian Indomie Goreng}

\section{1) Regresi Linear Sederhana}

Pengujian dilakukan untuk mengetahui pengaruh promosi dapat memperkuat keputusan pembelian indomie goreng, adapun hasil penelitian yaitu sebagai berikut:

\section{Tabel 9}

Uji Regresi Linear

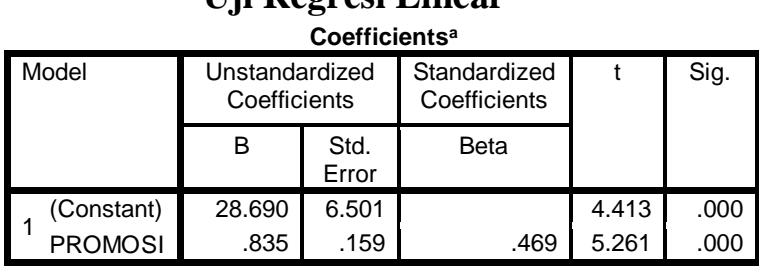

a. Dependent Variable: KEPUTUSAN_PEMBELIAN Sumber: Hasil Pengolahan Data Tahun

2020, SPSS Versi 21

Persamaan regresi yang digunakan adalah $\mathrm{Y}=\mathrm{a}+\mathrm{bX}$, maka dapat dihasilkan persamaan dari output adalah $\mathrm{Y}=28.690+$ 0.835X, maka hasil output SPSS maka diketahui coefficients produk sebesar 0.835 merupakan koefisien regresi, yang berarti jika instansi meningkatkan 1 satuan maka akan meningkatkan keputusan pembelian sebesar 0.835 .

\section{2) Uji Koefisien Korelasi}

Pengujian dilakukan untuk mengetahui mengetahui pengaruh promosi dapat memperkuat keputusan pembelian indomie goreng, adapun hasil penelitian yaitu sebagai berikut:
Tabel 10

Uji Uji Koefisien

Model Summaryb

\begin{tabular}{|l|r|r|r|r|}
\hline Model & $\mathrm{R}$ & $\begin{array}{c}\mathrm{R} \\
\text { Square }\end{array}$ & $\begin{array}{c}\text { Adjusted R } \\
\text { Square }\end{array}$ & $\begin{array}{c}\text { Std. Error of } \\
\text { the Estimate }\end{array}$ \\
\hline 1 & $.469^{\mathrm{a}}$ & .220 & .212 & 5.573 \\
\hline
\end{tabular}
a. Predictors: (Constant), PROMOSI
b. Dependent Variable: KEPUTUSAN_PEMBELIAN

Sumber: Hasil Pengolahan Data Tahun 2020,

SPSS Versi 21

Hasil pengolahan data menunjukan bahwa nilai $\mathrm{R}$ atau Multiple $\mathrm{R}$ menunjukan korelasi antara variabel bebas dengan variabel terikat sebesar 0.469 Dalam hal ini karena regresi linear sederhana dapat diketahui bahwa variabel bebas maka diakatakan bahwa korelasi antara promosi terhadap keputuasn pembelian adalah sebesar $46.9 \%$, dan sisanya $(100-46.9=$ $53.1 \%$ ) dipengaruhi oleh variabel lain yang tidak termasuk dalam variabel penelitian.

\section{3) Uji t}

Pengujian dilakukan untuk mengetahui pengaruh promosi dapat memperkuat keputusan pembelian indomie goreng, adapun hasil penelitian yaitu sebagai berikut:

\section{Tabel 11}

Uji t

Coefficients $^{a}$

\begin{tabular}{|c|c|c|c|c|c|}
\hline \multirow[t]{2}{*}{ Model } & \multicolumn{2}{|c|}{$\begin{array}{l}\text { Unstandardized } \\
\text { Coefficients }\end{array}$} & $\begin{array}{l}\text { Standardized } \\
\text { Coefficients }\end{array}$ & \multirow[t]{2}{*}{$t$} & \multirow[t]{2}{*}{ Sig. } \\
\hline & $B$ & $\begin{array}{l}\text { Std. } \\
\text { Error }\end{array}$ & Beta & & \\
\hline (Constant) & 28.690 & 6.501 & & 4.413 & .000 \\
\hline PROMOSI & .835 & 159 & .469 & 5.261 & .000 \\
\hline
\end{tabular}

Sumber: Hasil Pengolahan Data Tahun

2020, SPSS Versi 21

Dari data hasil pengujian maka independent yang dimasukan kedalam model regresi variabel maka dapat diketahui bahwa untuk mengetahui apakah promosi dapat memperkuat keputusan pembelian, didapatkan nilai $t_{\text {hitung }}$ sebesar 5.261 dan $t_{\text {tabel }}$ adalah sebesar 0.1638 (nilai $t_{\text {tabel }} \mathrm{n}=100$ ) 
maka dengan demikian dapat diketahui bahwa jika kriteria sesuai dengan $t_{\text {hitung }}>t_{\text {tabel }}$ maka Ho ditolak dan Ha diterima, yang artinya ada pengaruh signifikan antara promosi dengan keputusan pembelian Indomie Goreng.

\section{c. Pengaruh produk, dan Promosi dapat Memperkuat keputusan pembelian Indomie Goreng}

\section{1) Regresi Linear Berganda}

Pengujian dilakukan untuk mengetahui pengaruh produk dan harga terhadap keputusan pembelian Indomie Goreng, adapun hasil penelitian yaitu sebagai berikut:

Tabel 12

\section{Uji Regresi Linear} Coefficients $^{a}$

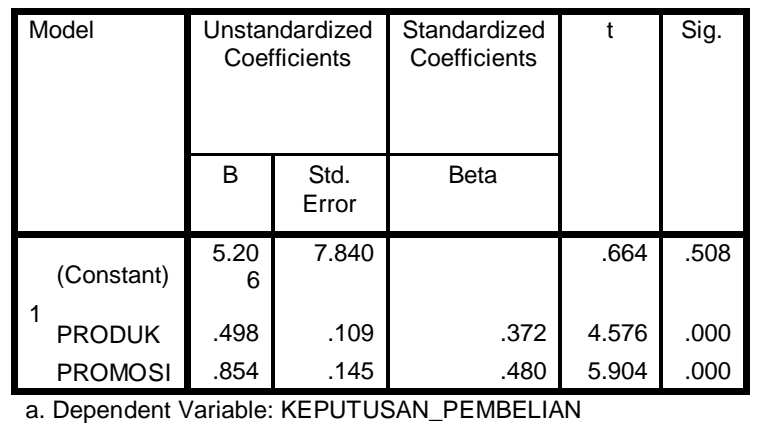

Sumber: Hasil Pengolahan Data Tahun 2020, SPSS Versi 21

Berdasarkan hasil perhitungan output SPSS diperoleh nilai $\mathrm{b} 1=0.498$ b2 $=0.854$ dan nilai $\mathrm{a}=5.206$ kemudian $\mathrm{a}$ dan $\mathrm{b}$ disusun ke dalam persamaan regresi linear berganda $\quad \mathrm{Y}=\mathrm{a}+\mathrm{b}_{1} \mathrm{X}_{1}+\mathrm{b}_{2} \mathrm{X}_{2}$ maka persamaan regresinya adalalah $\mathrm{Y}=5.206+0.498 \mathrm{X}_{1}+0.854 \mathrm{X}_{2}$. Itu artinya persamaan tersebut adalah bahwa nilai konstanta (a) sebesar 5.206 ini berarti bahwa apabila tidak ada penigkatan variabel produk dan promosi maka keputusan pembelian Indomie Goreng sebesar 5.206 , sedangkan nilai koefisien regresi (b1) sebesar 0,854 ini artinya terjadinya peningkat pada satuan variabel produk maka akan meningkatkan keputusan pembelian sebesar 0.854 satuan. Kemudian nilai koefisien regresi (b2) sebesar 0.498 ni berarti setiap terjadi peningkatan satu satuan Variabel Promosi akan meningkatkan keputusan pembelian sebesar 0.498 satuan.

\section{2) Uji Koefisien Determinasi}

Tabel 13

Uji Koefisien Determinasi

Model Summary ${ }^{b}$

\begin{tabular}{l|r|r|r|r|}
\hline $\begin{array}{l}\text { Mo } \\
\text { del }\end{array}$ & $\mathrm{R}$ & $\begin{array}{c}\mathrm{R} \\
\text { Square }\end{array}$ & $\begin{array}{c}\text { Adjusted R } \\
\text { Square }\end{array}$ & \multicolumn{2}{c|}{$\begin{array}{c}\text { Std. Error of the } \\
\text { Estimate }\end{array}$} \\
\hline 1 & $.599^{\mathrm{a}}$ & .359 & .345 & \\
\hline
\end{tabular}
a. Predictors: (Constant), PROMOSI, PRODUK
b. Dependent Variable: KEPUTUSAN_PEMBELIAN
Sumber: Hasil Pengolahan Data Tahun 2020,
SPSS Versi 21

Dari hasil perhitungan koefisien determinasi diatas, maka dapat diketahui bahwa nilai $\mathrm{R}^{2}$ adalah 0,359 maka dikali dengan $100 \%$ didapatkan nilai sebesar $35.9 \%$ artinya pengaruh produk dan promosi dapat memperkuat keputusan pembelian Indomie Goreng adalah sebesar $68.4 \%$ sedangkan sisanya $\quad(100-35.9=64.1 \%)$ dipengaruhi variabel lain yang tidak termasuk dalam penelitian.

\section{3) Uji F}

Adapun hasil penelitian untuk mengetahui pengaruh produk dan promosi untuk dapat memperkuat keputusan pembelian Indomie Goreng.

\section{Tabel 14 \\ Uji F \\ ANOVAa}

\begin{tabular}{|c|c|c|c|c|c|}
\hline Model & $\begin{array}{l}\text { Sum of } \\
\text { Squares }\end{array}$ & $\mathrm{df}$ & $\begin{array}{l}\text { Mean } \\
\text { Square }\end{array}$ & $\mathrm{F}$ & Sig. \\
\hline $\begin{array}{l}\text { Regression } \\
1 \text { Residual } \\
\text { Total }\end{array}$ & $\begin{array}{l}1400.191 \\
2503.519 \\
3903.710 \\
\end{array}$ & $\begin{array}{l}97 \\
99\end{array}$ & $\begin{array}{r}700.096 \\
25.809\end{array}$ & 27.126 & $.000^{\mathrm{b}}$ \\
\hline \multicolumn{6}{|c|}{$\begin{array}{l}\text { a. Dependent Variable: KEPUTUSAN_PEMBELIAN } \\
\text { b. Predictors: (Constant), PROMOSI, PRODUK }\end{array}$} \\
\hline \multicolumn{6}{|c|}{ Sumber: Hasil Pengolahan Data Tahun 2020, } \\
\hline
\end{tabular}


Dengan kriteria penilai jika $F_{\text {hitung }}>F_{\text {tabel }}$ maka Ho ditolak dan Ha diterima, sedangkan jika $\mathrm{F}_{\text {hitung }}<\mathrm{F}_{\text {tabel }}$ maka Ho diterima dan $\mathrm{Ha}$ ditolak, dengan taraf signifikan 5\%.Diperoleh nilai $\mathrm{F}_{\text {hitung }}$ sebesar 27.126 dan $F_{\text {tabel }}$ sebesar 2.70 Ini menunjukan bahwa $\mathrm{F}_{\text {hitung }}>\mathrm{F}_{\text {tabel }}$ dan juga sig sebesar $0,000<$ 0,05 sehingga dapat diketahui bahwa pengaruhnya signifikan. Maka dengan demikian dapat diambil kesimbulan bahwa Ho ditolak dan Ha diterima.Artinya Produk dan promosi dapat memperkuat sehingga berpengaruh signifikan terhadap keputusan pembelian Indomie Goreng.

\section{4) Moderated Regression Analysis (MRA)}

Hasil pengujian pengaruh produk terhadap keputusan pembelian :

\section{Tabel 15}

Moderated Regression Analysis

\begin{tabular}{|l|r|r|r|r|}
\hline Model & $\mathrm{R}$ & $\begin{array}{c}\mathrm{R} \\
\text { Square }\end{array}$ & $\begin{array}{c}\text { Adjusted R } \\
\text { Square }\end{array}$ & $\begin{array}{c}\text { Std. Error of the } \\
\text { Estimate }\end{array}$ \\
\hline 1 & $.358^{\mathrm{a}}$ & .128 & .119 & 5.893 \\
\hline
\end{tabular}
a. Predictors: (Constant), PRODUK
b. Dependent Variable: KEPUTUSAN_PEMBELIAN
Sumber: Hasil Pengolahan Data Tahun 2020,
SPSS Versi 21

Untuk hasil pengujian promosi dapat memperkuat atau memperlemah keputusan pembelian dapat dilihat pada hasil berikut ini:

\section{Tabel 16}

Moderated Regression Analysis Model Summary

\begin{tabular}{l|r|r|r|r|}
\hline Model & $R$ & R Square & $\begin{array}{c}\text { Adjusted R } \\
\text { Square }\end{array}$ & $\begin{array}{c}\text { Std. Error of the } \\
\text { Estimate }\end{array}$ \\
\hline 1 & $.601^{\mathrm{a}}$ & .362 & .342 & 5.095 \\
\hline
\end{tabular}
$\begin{aligned} & \text { a. Predictors: (Constant), PRODUK*PROMOSI, PROMOSI, } \\
& \text { PRODUK }\end{aligned}$

Sumber: Hasil Pengolahan Data Tahun 2020, SPSS Versi 21

Berdasarkan hasil pengujian diatas menunjukkan bahwa pengaruh produk terhadap keputusan pembelian adalah sebesar $12.8 \%$. Serta hasil pengujian setelah adanya variabel moderasi yaitu promosi dapat memperkuat atau meningkatkan keputusan pembelian menjadi $36.2 \%$.

\subsection{Pembahasan}

\section{Pengaruh produk terhadap keputusan pembelian Indomie Goreng}

Pengujian dilakukan untuk mengetahui pengaruh produk terhadap keputusan pembelian Indomie Goreng, adapun hasil penelitian yaitu persamaan regresi yang digunakan adalah $\mathrm{Y}=\mathrm{a}+\mathrm{bX}$, maka dapat dihasilkan persamaan dari output adalah $\mathrm{Y}=40.941+0.480 \mathrm{X}$, maka hasil output SPSS maka diketahui coefficients produk sebesar 0.480 merupakan koefisien regresi, yang berarti jika instansi meningkatkan 1 satuan maka akan meningkatkan keputusan pembelian sebesar 0.480

Hasil pengujian analisis koefisien korelasi parsial dilakukan untuk mengetahui pengaruh produk terhadap keputusan pembelian Indomie Goreng, adapun hasil penelitian yaitu $\mathrm{R}$ atau Multiple $\mathrm{R}$ menunjukan korelasi antara variabel bebas dengan variabel terikat sebesar 0.358 Dalam hal ini karena regresi linear sederhana dapat diketahui bahwa variabel bebas maka diakatakan bahwa korelasi antara produk terhadap keputuasn pembelian adalah sebesar 35.8\%, dan sisanya (100-35.8= $64.2 \%$ ) dipengaruhi oleh variabel lain yang tidak termasuk dalam variabel penelitian.

Hasil uji $t$ digunakan untuk menguji pengaruh variabel independen secara parsial terhadap variabel dependen, apakah pengaruhnya signifikan atau tidak. Pengujian dilakukan untuk mengetahui pengaruh produk terhadap keputusan pembelian Indomie Goreng, adapun hasil penelitian yaitu hasil pengujian maka independent yang dimasukan kedalam model regresi variabel maka dapat diketahui bahwa untuk mengetahui apakah produk memiliki pengaruh terhadap keputusan pembelian. Nilai $t_{\text {hitung }}$ sebesar 3.797 dan $t_{\text {tabel }}$ adalah 
sebesar 0.1638 (nilai $t_{\text {tabel }} \mathrm{n}=100$ ) maka dengan demikian dapat diketahui bahwa jika kriteria sesuai dengan $t_{\text {hitung }}>t_{\text {tabel }}$ maka Ho ditolak dan Ha diterima, yang artinya ada pengaruh signifikan antara Produk dengan keputusan pembelian Indomie Goreng.

\section{Promosi dapat memperkuat keputusan pembelian Indomie Goreng \\ Pengujian dilakukan untuk} mengetahui promosi dapat memperkuat keputusan pembelian Indomie Goreng, adapun hasil penelitian yaitu persamaan regresi yang digunakan adalah $\mathrm{Y}=\mathrm{a}+\mathrm{bX}$, maka dapat dihasilkan persamaan dari output adalah $\mathrm{Y}=28.690+0.835 \mathrm{X}$, maka hasil output SPSS maka diketahui coefficients produk sebesar 0.835 merupakan koefisien regresi, yang berarti jika instansi meningkatkan 1 satuan maka akan meningkatkan keputusan pembelian sebesar 0.835 .

Hasil pengujian analisis koefisien korelasi parsial dilakukan untuk mengetahui promosi dapat memperkuat keputusan pembelian Indomie Goreng, adapun hasil penelitian yaitu $\mathrm{R}$ atau Multiple $\mathrm{R}$ menunjukan korelasi antara variabel bebas dengan variabel terikat sebesar 0.469 Dalam hal ini karena regresi linear sederhana dapat diketahui bahwa variabel bebas maka diakatakan bahwa korelasi antara promosi terhadap keputuasn pembelian adalah sebesar $46.9 \%$, dan sisanya (100-46.9= $53.1 \%$ ) dipengaruhi oleh variabel lain yang tidak termasuk dalam variabel penelitian.

Hasil uji $\mathrm{t}$ digunakan untuk menguji pengaruh variabel independen secara parsial terhadap variabel dependen, apakah pengaruhnya signifikan atau tidak. Pengujian dilakukan untuk mengetahui promosi dapat memperkuat keputusan pembelian Indomie Goreng, adapun hasil penelitian yaitu hasil pengujian maka independent yang dimasukan kedalam model regresi variabel maka dapat diketahui bahwa untuk mengetahui apakah produk memiliki pengaruh terhadap keputusan pembelian. nilai $t_{\text {hitung }}$ sebesar 5.261 dan $t_{\text {tabel }}$ adalah sebesar 0.1638 (nilai $t_{\text {tabel }} n=100$ ) maka dengan demikian dapat diketahui bahwa jika kriteria sesuai dengan $t_{\text {hitung }}>t_{\text {tabel }}$ maka Ho ditolak dan Ha diterima, ada pengaruh signifikan antara promosi dengan keputusan pembelian Indomie Goreng.

Tujuan utama promosi adalah menginformasikan, mempengaruhi dan membujuk serta mengingatkan pelanggan sasaran tentang pemasaran dan bauran pemasaran. Dengan memperhatikan hal diatas maka diperlukan persiapan ataupun sarana promosi agar apa yang diinginkan perusahaan dapat memenuhi sasaran dan efisien [4] . Untuk melakukan promosi dapat digunakan sarana seperti (1)eriklanan, (2) Promosi penjualan, (3) Publisitas dan (4)Penjualan pribadi [4].

\section{Pengaruh produk, dan Promosi dapat Memperkuat keputusan pembelian Indomie Goreng}

Pengujian Analisis regresi ganda dilakukan untuk mengetahui Pengaruh produk, dan Promosi dapat Memperkuat keputusan pembelian Indomie Goreng, adapun hasil penelitian yaitu hasil perhitungan output SPSS diperoleh nilai b1 $=0.498 \mathrm{~b} 2=0.854$ dan nilai $\mathrm{a}=5.206$ kemudian a dan $\mathrm{b}$ disusun ke dalam persamaan regresi linear berganda $\mathrm{Y}=\mathrm{a}$ $+b_{1} X_{1}+b_{2} X_{2}$ maka persamaan regresinya adalalah $\mathrm{Y}=5.206+0.498 \mathrm{X}_{1}+0.854 \mathrm{X}_{2}$. Itu artinya persamaan tersebut adalah bahwa nilai konstanta (a) sebesar 5.206 ini berarti bahwa apabila tidak ada penigkatan variabel produk dan promosi maka keputusan pembelian Indomie Goreng sebesar 5.206 , sedangkan nilai koefisien regresi (b1) sebesar 0,854 ini artinya terjadinya peningkat pada satuan variabel produk maka akan meningkatkan keputusan pembelian sebesar 0.854 satuan. Kemudian nilai koefisien regresi (b2) sebesar 0.498 ini 
berarti setiap terjadi peningkatan satu satuan Variabel Promosi akan meningkatkan keputusan pembelian sebesar 0.498 satuan.

Hasil perhitungan koefisien
determinasi yang telah dilakukan menunjukkan bahwa nilai $\mathrm{R}^{2}$ adalah 0,359 maka dikali dengan $100 \%$ didapatkan nilai sebesar $35.9 \%$ artinya pengaruh produk dan promosi dapat memperkuat keputusan pembelian Indomie Goreng adalah sebesar $68.4 \%$ sedangkan sisanya (100$35.9=64.1 \%$ ) dipengaruhi variabel lain yang tidak termasuk dalam penelitian.

Hasil perhitungan uji $\mathrm{F}$ menunjukkan bahwa nilai $F_{\text {hitung }}$ sebesar 27.126 dan $F_{\text {tabel }}$ sebesar 2.70 maka $F_{\text {hitung }}>F_{\text {tabel }}$ dan juga sig sebesar $0,000<0,05$ sehingga dapat diketahui bahwa pengaruhnya signifikan. Maka dengan demikian dapat diambil kesimbulan bahwa Ho ditolak dan $\mathrm{Ha}$ diterima.Artinya Produk dan promosi dapat memperkuat sehingga berpengaruh signifikan terhadap keputusan pembelian Indomie Goreng.

Hasil pengujian Moderated Regression Analysis (MRA) yang telah dilakukan menunjukkan bahwa pengaruh produk terhadap keputusan pembelian adalah sebesar $12.8 \%$. Serta hasil pengujian setelah adanya variabel moderasi yaitu promosi dapat memperkuat atau meningkatkan keputusan pembelian menjadi $36.2 \%$.

\section{KESIMPULAN}

Setelah melakukan penelitian dengan menyebarkan kuisioner, yang dijawab oleh responden (pelanggan) PT. Indomarco Adi Prima Cabang Lubuklinggau yaitu sebagai berikut:

1. Pengaruh produk terhadap keputusan pembelian Indomie Goreng, dapat diketahui dari hasil perhitungan persamaan regresi perhitungan dengan output adalah $\mathrm{Y}=40.941+0.480 \mathrm{X}$, maka hasil output SPSS maka diketahui coefficients produk sebesar 0.480 merupakan koefisien regresi, yang berarti jika instansi meningkatkan 1

satuan maka akan meningkatkan keputusan pembelian sebesar 0.480, hasil perhitungan $\mathrm{R}$ atau Multiple $\mathrm{R}$ yang menunjukkan korelasi antara produk terhadap keputuasn pembelian adalah sebesar $35.8 \%$, dan sisanya (100-35.8= $64.2 \%$ ) dipengaruhi oleh variabel lain yang tidak termasuk dalam variabel penelitian, serta hasil uji $\mathrm{t}$ yang menunjukkan nilai $t_{\text {hitung }}$ sebesar 3.797 dan $t_{\text {tabel }}$ adalah sebesar 0.1638 (nilai $t_{\text {tabel }} n=100$ ) maka dengan demikian dapat diketahui bahwa jika kriteria sesuai dengan $t_{\text {hitung }}>t_{\text {tabel }}$ maka Ho ditolak dan Ha diterima, yang artinya ada pengaruh signifikan antara Produk dengan keputusan pembelian Indomie Goreng. Moderasi promosi dapat memperkuat keputusan pembelian Indomie Goreng, dapat diketahui dari nilai perhitungan persamaan regresi perhitungan dengan output adalah $\mathrm{Y}=$ $28.690+0.835 \mathrm{X}$, maka hasil output SPSS maka diketahui coefficients produk sebesar 0.835 merupakan koefisien regresi, yang berarti jika instansi meningkatkan 1 satuan maka akan meningkatkan keputusan pembelian sebesar 0.835 , hasil perhitungan $\mathrm{R}$ atau Multiple $\mathrm{R}$ yang menunjukkan korelasi antara promosi terhadap keputuasn pembelian adalah sebesar $46.9 \%$, dan sisanya $(100-46.9=53.1 \%)$ dipengaruhi oleh variabel lain yang tidak termasuk dalam variabel penelitian.

2. Pengaruh produk, dan Promosi dapat Memperkuat keputusan pembelian Indomie Goreng, dapat diketahui dari nilai perhitungan uji $\mathrm{F}$ menunjukkan bahwa nilai $F_{\text {hitung }}$ sebesar 27.126 dan $F_{\text {tabel }}$ sebesar 2.70 maka $F_{\text {hitung }}>F_{\text {tabel }}$ dan juga sig sebesar $0,000<0,05$ sehingga dapat diketahui bahwa pengaruhnya signifikan. Maka dengan demikian dapat diambil kesimbulan bahwa Ho ditolak dan Ha diterima.Artinya Produk dan 
promosi dapat memperkuat sehingga berpengaruh signifikan terhadap keputusan pembelian Indomie Goreng serta Hasil pengujian Moderated Regression Analysis (MRA) yang menunjukkan pengaruh produk terhadap keputusan pembelian adalah sebesar $12.8 \%$. Serta hasil pengujian setelah adanya variabel moderasi yaitu promosi dapat memperkuat atau meningkatkan keputusan pembelian menjadi $36.2 \%$.

\section{SARAN}

Setelah mendapatkan hasil penelitian yang telah penulis lakukan. Maka penulis memberikan saran sebagai berikut :

1. Bagi Perusahaan

a. PT. Indomarco Adi Prima Cabang Lubuklinggau dapat mempertimbangkan memberikan mutu lebih terhadap produk indomie goreng sehingga pelanggan memilih varial lebih dengan kualitas produk yang baik sehingga dapat lebih meningkatkan jumlah konsumen atau pelanggan PT. Indomarco Adi Prima Cabang Lubuklinggau.

b. PT. Indomarco Adi Prima Cabang Lubuklinggau dapat melakukan promosi dengan lebih maksimal sehingga produk indomie goreng dapat lebih dikenali dan diminati oleh pelanggan baru .

c. PT. Indomarco Adi Prima Cabang Lubuklinggau dapat memberikan produk terbaik dan menyampaikan informasi produk melalui kegiatan promosi yang dapat memberikan potongan harga untuk menarik minat pembelian pelanggan yang lebih banyak.

2. Bagi Pimpinan

Pimpinan dapat mengetahui pengaruh produk terhadap keputusan pembelian indomie goreng dengan variabel promosi sebagai moderasi, sehingga dapat membuat keputusan yang lebih baik untuk dapat meningkatkan tingkat penjualan produk indomie goreng.

3. Bagi Peneliti Selanjutnya

Untuk penelitian selanjutnya dapat memperluas variabel penelitian sehingga hasil lebih luas lagi, dimana untuk penelitian yang penulis lakukan terdapat 3 (tiga) variabel yaitu produk, promosi dan keputusan pembelian diharapkan agar untuk lebih menyempurnakan yang lebih besar sehingga didapatkan hasil penelitian yang lebih baik.

\section{DAFTAR PUSTAKA}

[1] B. R. T. Putri, "Manajemen Pemasaran," vol. 1, pp. 11-40, 2017.

[2] L. Hermawan, "Dilema Diversifikasi Produk: Meningkatkan Pendapatan Atau Menimbulkan Kanibalisme Produk," J. Stud. Manaj., vol. 9, no. 2, pp. 143-144, 2015.

[3] Y. W. Susanto, "Pengaruh Inovasi Produk, Kualitas Produk Dan Harga Terhadap Keputusan Pembelian Di Toko Roti Dan Kue Ferissa Bantul Yogyakarta," pp. 1-12, 2017.

[4] R. dan G. E. Budiharja, "Pengaruh Kualitas Produk, Harga, Promosi Dan Brand Image Terhadap Keputusan Pembelian Produk Aqua," J. STIE SEMARANG, vol. 53, no. 9, pp. 1689-1699, 2016.

[5] Supriyanto and B. Andriansyah, "Pengaruh Promosi Dan Layanan Terhadap Keputusan Nasabah Kredit Usaha Mikro Di Pt. Bank Mandiri (Persero) Tbk. Cabang Tugumulyo Musi Rawas," vol. 24, no. 2, 2019.

[6] M. L. Hedynata and W. E.D.Radianto, "Strategi Promosi Dalam Meningkatkan Penjualan 
Luscious Chocolate Potato Snack," $J$. Manaj., vol. 1, no. 1, pp. 87-96, 2016.

[7] Aprianto and Y. Ronal, "Pengaruh Promosi Dan Pelayanan Terhadap Keputusan Pembelian Konsumen Sepeda Motor Pada Pd Utama Motor Lubuklinggau," vol. 21, no. 3, pp. 74-91, 2016.

[8] A. Maftukhah, "Pengetahuan Konsumen dan Keputusan Menjadi Nasabah," 2015.

[9] M. E. Saputri, "Pengaruh Perilaku Konsumen Terhadap Keputusan Pembelian," J. Adm. Bisnis, vol. 3, no. 2, pp. 1-8, 2016.

[10] S. Oktavianti, "Analisis Tingkat Kualitas Produk dan Tingkat Pelayanan Kentucky Fried Chicken (KFC) Cabang Palembang Trade Centre," J. Manaj. Dan Bisnis Sriwij., vol. 16, no. 4, pp. 203-211, 2018.

[11] D. P. Atmaja and M. F. Adiwinata, "Pengaruh Produk, Harga, Lokasi Dan Kualitas Layanan Terhadap Keputusan Pembelian Di Kopitiam Oey Surabaya," Manajemen, vol. 53, no. 9, pp. 1689-1699, 2016.

[12] F. R. Afifi and Ngatno, "Pengaruh promosi, harga dan pelayanan terhadap keputusan pembelian toyota dyna dengan jenis usaha sebagai variabel moderasi," 2015.

[13] G. Ratela and R. Taroreh, "Analisis Strategi Diferensiasi, Kualitas Produk Dan Harga Terhadap Keputusan Pembelian Di Rumah Kopi Coffee Island," J. Ris. Ekon. Manajemen, Bisnis dan Akunt., vol. 4, no. 1, pp. 460-471, 2016.
[14] H. Wijaya and H. Sirine, "Strategi Segmenting, Targeting, Positioning Serta Strategi Harga Pada Perusahaan Kecap Blekok Di Cilacap," Ajie, vol. 1, no. 3, pp. 175-190, 2016.

[15] T. S. Abiidurrahman, "Pengaruh Kualitas Produk Dan Daya Tarik Iklan Terhadap Keputusan Pembelian Produk Mie Sedaap Cup,” pp. 1-16, 2015.

[16] Sugiyono, Metode Penelitian Administrasi. Bandung: Alfabeta, 2017.

[17] D. Dermawan, Metode Penelitian Kualitatif. Bandung: Remaja Rosdakarya, 2014.

[18] Bryan and E. Haryadi, "Analisis Pengaruh Variabel Moderasi Switching Costs Terhadap Hubungan Service Performance Dan Customer Loyalty Member Celebrity Fitness Jakarta," J. Manaj., vol. 15, no. 1, pp. 52-71, 2018.

[19] P. D. I. Savitri and Dwirandra, "Time Budget Pressure Sebagai Pemoderasi Pengaruh Due Professional Care dan Pengalaman Audit Pada Kualitas Audit," E-Jurnal Akunt. Univ. Udayana, vol. 1, no. 1, 2018.

[20] N. A. Dewi, R. Rahmawati, and A. Mukid, "Analisis Kepuasan Pengunjung Menggunakan Second Order Confirmatory Factor Analysis Pada Structural Equation Modeling," Concept Commun., vol. null, no. 23, pp. 301-316, 2015. 